\title{
Modeling the relationship between perceived values, e-satisfaction, and e-loyalty
}

\author{
Li Wang ${ }^{a^{*}}$ and Manoch Prompanyo ${ }^{\mathrm{b}}$
}

${ }^{a}$ Ph.D. Candidate, Management, School of Management, Shinawatra University, Bangkok, Thailand ${ }^{b}$ Ph.D., Management, School of Management, Shinawatra University, Bangkok, Thailand

\section{H R O N I C L E}

\section{Article history:}

Received: February 16, 2020

Received in revised format:

March 222020

Accepted: March 22, 2020

Available online:

March 25, 2020

Keywords:

Perceived Value

E-Satisfaction

E-Loyalty

Cross-border E-commerce

\section{A B S T R A C T}

Perceived value, E-satisfaction, and E-loyalty are widely discussed in the practitioner literate and considered as critical factors for the success of E-commerce. Those constructs still contribute to the significant impacts on cross-border E-commerce, which is a part of E-commerce. However, Cross-border Ecommerce, particularly for Sino-Thai Cross-border E-commerce, as an emerging market, does not draw enough attention from scholars. Hence, the lack of theoretical and empirical researches leads to few or limited support or guide for suppliers and governments to tackle this complex issue. The study aims to develop and empirically examine the interrelationships between Perceived Value (FV, PDV, EV \& SV), E-satisfaction, and E-loyalty in Sino-Thai cross border e-commerce based on China's customers. Meanwhile, it attempts to manifest the mediation impacts on the associations between Perceived Value (FV, PDV, EV \& SV) and E-loyalty through E-satisfaction. The questionnaire lasted over 3 months in 2019 for data collection and was conducted with 381 respondents who had shopping experience in the platforms of Sino-Thai Cross-border E-commerce, by using self-administrated questionnaires. Confirmed factor analysis and structural equational model were performed in Amos 24 to test the hypotheses and analyze the collected data. The empirical findings elucidate that perceived functional value, procedural value, and social value except for emotional value, significantly and positively impact on e-loyalty through e-satisfaction. Moreover, the findings stress that the full mediating effect of e-satisfaction on the relationships between FV, PDV, SV, and E-loyalty as well. In light of this, the findings of this study make an effort on the development of the model based on those 3 constructs in Cross-border E-commerce and offer strategic insights for the entrepreneurs and governments in this field.

C) 2020 by the authors; licensee Growing Science, Canada

\section{Introduction}

As a significant part of Asian trade, the Sino-Thai business makes great contribution to the sustainable development of Asia and even the world economy (Ngo et al., 2019; Quan et al., 2020). With the extensive use of the Internet and rapid development of information technology, bilateral trades between China and Thailand has gradually changed from the traditional trade model to a more flexible, convenient, and efficient cross-border e-commerce model containing more trading opportunities and potentials for both countries, which will enter a new booming stage. Cross-border E-commerce is defined as the import and export activities of cross-border trade conducted through e-commerce methods by transaction subjects from different customs borders (Cross-border E-commerce in China: A New Opportunity, 2019). It expands e-commerce to a new stage, which enables global customers and suppliers to trade products and services without geographical barriers in its real sense. The report of the Office of Strategic Policy and Trade Strategy of Thailand's Ministry of Commerce stated that Thailand's exports amounted to $\$ 18.094$ billion in April 2018, which dramatically surged upward than before. The Chinese articles indicated that the most significant reason behind this phenomenon was cross-border e-commerce, which bridged the gap between suppliers and consumers in two countries (Is Chinese durian love a fad or forever, 2018). The increase rate of total quantities of online Thai durian sell in China was almost 700\% in 2018, which was another strong evidence to support the above statement (Chinese Demand for Thai Durian Skyrockets, 2018). However, Cross-border E-commerce not only shapes consumers' shopping

* Corresponding author. Tel. :+8613806785099

E-mail address: 7618046@qq.com (L. Wang) 
behaviors and creates enormous business opportunities but also aggravates the global competition, relying on its trades without boundary. In such customer-focused competitive global markets, being able to build customer loyalty is the most superior and practical approach in gaining market share (Jarvis \& Mayo, 1986), reducing business-operations costs (Reichheld \& Detrick, 2003), raising barriers for new entrants (Sharp \& Sharp, 1997; Nguyen et al., 2020) and developing sustainable competitive advantage (Kotler \& Singh, 1981). Unfortunately, Sino-Thai Cross-border E-commerce as an emerging market, theoretical, and empirical researches are relatively rare which results in lack of academic support or guide for suppliers and governments to tackle this complex issue. Perceived value and customer satisfaction as the main antecedents for customer loyalty significantly influence customers attitudinal and behavioral loyalty towards products or services (Kungumapriya \& Malarmathi, 2018).

Consequently, the main objectives of this research are as following:

i. To manifest the interrelationships between Perceived Value (FV, PDV, EV \& SV), E-satisfaction, and E-loyalty in Sino-Thai cross border e-commerce,

ii. To verify the mediation impacts on the associations between Perceived Value (FV, PDV, EV \& SV) and E-loyalty through E-satisfaction in Sino-Thai cross border e-commerce,

iii. To explore and identify the constructs of Perceived Value in Sino-Thai Cross Border E-commerce.

\section{Literature review}

\subsection{Perceived Value}

Perceived Value is referred as "comparison of tangible and intangible benefits from the generic as well as the supplementary levels of a product and the total costs of production and usage of a product" (Nilson, 1992). Most scholars asserted that perceived value was highly situational and context-dependent (e.g., Brady \& Robertson, 1999). To truly reflect the changeable and dynamic nature of the perceived value, the unidimensional measurement had been replaced by multidimensional measurement (e.g., Sheth et al., 1991). The widely recognized and applied the multidimensional measurement of Perceived Value was identified by Sheth et al. (1991), who proposed five dimensions, including social, emotional, functional, epistemic, and conditional dimensions on measuring the perceived value. In a later study by Sweeney and Soutar (2001), they reduced the five dimensions to three, as the epistemic and conditional values were too transient. Functional value is defined as "the perceived utility acquired from an alternative's capacity for functional, utilitarian or physical performance" (Sheth et al., 1991); Social value is conceptualized as the acceptability at the level of the individuals' relationship with his social environment (Sheth et al., 1991); emotional value is referred to "the perceived utility acquired from an alternative's capacity to arouse feelings or affective states" (Sheth et al., 1991). Meanwhile, numerous scholars advocated that, under the context of e-commerce, customers garnered substantial attention on the procedural value like convenience (Kassim \& Adbullah, 2008), website design (Hansen \& Jonsson, 2014), and security (Hansen \& Jonsson, 2014), which was typically viewed as customers' perception of benefit or advantage from their association with an organization's offering (Carlson et al., 2015; Goutam \& Gopalakrishna, 2018). Consequently, based on the prior literature, in this research, the dimensions of the perceived value include functional, emotional, social, and procedural vales in the context of Sino-Thai Cross-border E-commerce.

\subsection{E-satisfaction}

In this study, E-satisfaction is defined as the contentment of a consumer concerning his or her prior purchasing experiences with a given retail-oriented website (Rolph \& Srinivasan, 2003). The correlation between customer satisfaction and loyalty had drawn attention from scholars in a long time. According to the previous literature, most scholars believed that satisfaction had a significant impact on loyalty. Similar in the context of e-commerce, after reviewing 45 loyalty related articles, it was found that more than 30 articles (more than two-thirds of the literature) analyzed and verified the relationship between loyalty and satisfaction and stressed that customer satisfaction was able to enhance customer loyalty (e.g., Hansen \& Jonsson, 2014). It is also a shred of strong evidence to support that customer satisfaction as an essential indicator of loyalty could not be neglected when measuring loyalty.

\subsection{E-loyalty}

The broad of e-loyalty discussed in the past scientific papers concentrated on the extensive views of e-loyalty and its constructs. E-loyalty derived from traditional loyalty involves the features of the conventional concept. Hence, according to Rolph and Srinivasan (2003), e-loyalty is referred to as "the customer's favorable attitude toward an electronic business resulting in repeat buying behavior". Numerous studies are focusing on exploring and determining the interrelationship between the perceived value, customer satisfaction, and customer loyalty by employing different theoretical models. Among these researches, the best-known model of loyalty model is the American Customer Satisfaction Index, the only national customer satisfaction measure, whose results are consistent, reliable, and proven over time (The Science of Customer Satisfaction, n.d.). This model well expresses the interrelationship between perceived value, customer satisfaction, and customer loyalty, and also highlights the mediated role of customer satisfaction, impacting on the relationship between perceived value and customer loyalty as 
well. At the initial stage, ACSI collected data from 180,000 customer interviewees to generate and test the Customer satisfaction Index and its model. Till now, it has been analyzed over 10 economic sectors and 46 critical industries, including ecommerce, and has spread to more than 15 countries (Unique Benchmarking Capability, n.d.).

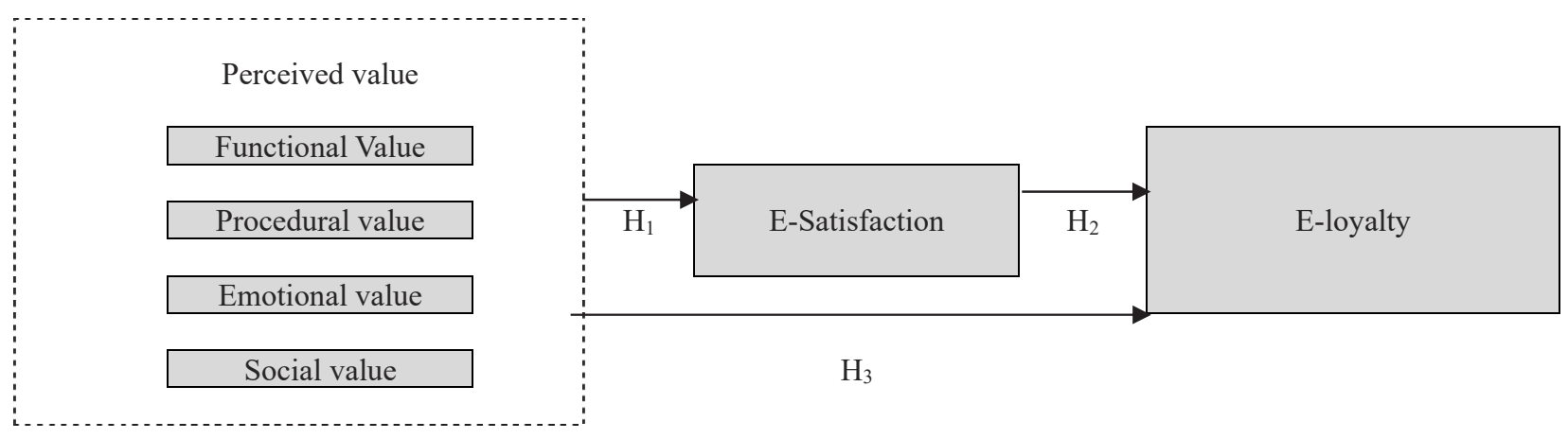

Fig.1. The Conceptual Model

Additionally, in recent years, scholars have made efforts to modify and develop the perceived value in their associations model to a multi-dimensional measurement, but such studies are still relatively rare. Jayakodi et al. (2016) explored and validated that customer satisfaction had a significant influence on the relationships between functional, social, emotional, epistemic value and customer loyalty in the TV industry. Liu \& Zhang (2016) confirmed functional, emotional, social, and procedural value as the perceived value in the customer loyalty model in China's e-commerce market. Consequently, based on the literature review, the conceptual model is proposed (Fig. 1) and the hypotheses are as follow:

$\mathbf{H}_{1}$ Perceived Value has a positive relation with E-satisfaction.

SubH $_{1 a}$ Perception of Functional Value has a positive relation with E-satisfaction.

$\mathbf{S u b H}_{1 \mathbf{b}}$ Perception of Procedural Value has a positive relation with E-satisfaction.

$\mathbf{S u b H}_{1 \mathbf{c}}$ Perception of Emotional Value has a positive relation with E-satisfaction.

SubH $_{1 d}$ Perception of Social Value has a positive relation with E-satisfaction.

$\mathbf{H}_{2}$ E-Satisfaction has a positive relation with E-loyalty.

$\mathbf{H}_{3}$ Perception Value has a positive relation with E-loyalty.

SubH $_{3}$ Perception of Functional Value has a positive relation with E-loyalty.

$\mathrm{SubH}_{3 \mathbf{b}}$ Perception of Procedural Value has a positive relation with E-loyalty.

$\mathbf{S u b H}_{3 \mathbf{c}}$ Perception of Emotional Value has a positive relation with E-loyalty.

$\mathbf{S u b H}_{3 \mathbf{d}}$ Perception of Social Value has a positive relation with E-loyalty.

$\mathbf{H}_{4}$ E-satisfaction mediates the relationship between Perceived Value and E-loyalty.

$\mathbf{S u b H}_{4 a}$ E-satisfaction mediates the relationship between Functional Value and E-loyalty.

SubH $_{4 b}$ E-satisfaction mediates the relationship between Procedural Value and E-loyalty.

$\mathrm{SubH}_{4 \mathrm{c}}$ E-satisfaction mediates the relationship between Emotional Value and E-loyalty.

$\mathrm{SubH}_{4 d}$ E-satisfaction mediates the relationship between Social Value and E-loyalty.

\section{Methodology}

\subsection{Research instrument and pilot test}

This research uses survey questionnaires as the principal tool for gathering and collecting data. The items in the questionnaire are formulated and developed by the existing classic measurements validated by previous researchers. The questionnaire is designed with three parts, including the demographic queries, the online behavior related queries, and the conceptual-framework-related queries. Part 3 is described in a seven-point Likert scale according to (Brown, 2011), as self-reported agreement towards a statement, which is anchored by (1) strongly disagree and (7) strongly agree. To reach the target respondents of this research, two versions of the questionnaire (English and Chinese), are developed. The initial research questionnaires were firstly reviewed by professors and experts from both Chinese and Thai universities to remove misunderstandings and ambiguities of expression in the questionnaire. Then the Chinese one was back-translated into English to compare with the original English version to make sure there was no difference between those two versions. After that, 30 customers aging within the range of 18 to 44, were selected from the platforms of Sino-Thai Cross Border E-commerce for this Pilot Test. After the Pilot Test, the quality of research questionnaire was improved, which was an official version of this research. 
This research conducts both quantitative study and purposive sampling to collect empirical data by using the self-administrated questionnaire distributed among the China's online customers aging 18 to 44, who must have done online transaction(s) via the Sino-Thai Cross-border platforms. The survey was conducted for over 2 months and 400 questionnaires were distributed, which finally resulted in 327returens. Therefore, the number of returns is more than the minimum required size 200 , which is reliable for further analysis. According to the analysis of sample distribution, female respondents accounted for $80.7 \%$ of the total, while only $19.3 \%$ were from the male side. It demonstrates the majorities of the respondents were between $25-34$ old, taking up over than half (52\%), while 27.2\% were aged $18-24$ and $20.7 \%$ are $35-44$. In regard to the education level, $37.6 \%$ held a bachelor's degree, $25 \%$ had college education, $24.2 \%$ had master degree and above. In terms of career (Figure 4.4), students accounted for $23 \%$, followed by those in the service industry (17.1\%), Freelancer (15.6\%) and so forth; Regarding with monthly income, over $70 \%$ indicated their monthly income was more than $¥ 6,000$; $93 \%$ respondents purchased at least 3 times in platforms of Sino-Thai Cross border E-commerce, among which $49.2 \%$ of interviewees bought 6-10 times, and $25.7 \%$ purchased even above 10 times in one year. Refer to the weekly respondents' internet time (Figure 4.7), respondents surfing the internet for 4-6 hours and 1-3 hours per day accounted for 38.5\% and 30.9\%, respectively, which made up nearly $70 \%$ of the total. Based on the demographic analysis, the target customer of this research could be elaborated as $18-44$ old working female customers with high education background and monthly income, normally surfing website 1-6 hours on per day (and preferring to purchase products from the platforms of Sino-Thai Cross-border E-commerce more than 3 times per year. Those characteristics of target customers are consistent with China's Cross-border E-commerce report (2019). Consequently, the samples of this study are reliable and effective which is considered as the representative of the entire target.

\subsection{Confirmatory Factor Analysis (CFA): Reliability and Validity Test}

Table 1

The Result of the Composite Reliability \& Convergent Validity

\begin{tabular}{|c|c|c|c|c|c|c|c|c|c|}
\hline \multirow{2}{*}{ Construct } & \multirow{2}{*}{ Item } & \multicolumn{4}{|c|}{ Parameter Significance Estimation } & \multirow{2}{*}{$\begin{array}{l}\text { FL* } \\
\text { Std. }\end{array}$} & \multirow{2}{*}{$\begin{array}{c}\text { IR* } \\
\text { SMC }\end{array}$} & \multirow{2}{*}{$\begin{array}{c}\mathrm{CR}^{*} \\
\mathrm{CR}\end{array}$} & \multirow{2}{*}{$\begin{array}{c}\mathrm{CV}^{*} \\
\mathrm{AVE}\end{array}$} \\
\hline & & Unstd. & S.E. & t-value & $\mathbf{P}$ & & & & \\
\hline \multirow[t]{4}{*}{$\mathrm{FV}$} & FV1 & 1.000 & & & & .788 & .621 & .896 & .683 \\
\hline & FV3 & 1.064 & .067 & 15.850 & $* * *$ & .823 & 677 & & \\
\hline & FV2 & 1.094 & .068 & 16.091 & $* * *$ & .834 & .696 & & \\
\hline & FV4 & 1.051 & .063 & 16.614 & $* * *$ & .859 & .738 & & \\
\hline \multirow[t]{4}{*}{ PDV } & PDV1 & 1.000 & & & & .765 & .585 & .888 & .666 \\
\hline & PDV2 & 1.055 & .072 & 14.643 & $* * *$ & .799 & .638 & & \\
\hline & PDV3 & 1.160 & .074 & 15.760 & $* * *$ & .859 & .738 & & \\
\hline & PDV4 & 1.037 & .067 & 15.366 & $* * *$ & .837 & .701 & & \\
\hline \multirow[t]{3}{*}{ EV } & EV1 & 1.000 & & & & .862 & .743 & .881 & .711 \\
\hline & EV2 & .985 & .057 & 17.254 & $* * *$ & .848 & .719 & & \\
\hline & EV3 & 1.019 & .061 & 16.749 & $* * *$ & .819 & .671 & & \\
\hline \multirow[t]{3}{*}{ SV } & SV1 & 1.000 & & & & .876 & .767 & .914 & .779 \\
\hline & SV2 & 1.008 & .048 & 21.183 & $* * *$ & .891 & .794 & & \\
\hline & SV3 & 1.011 & .048 & 20.892 & $* * *$ & .881 & .776 & & \\
\hline \multirow[t]{3}{*}{ ES } & ES1 & 1.000 & & & & .825 & .681 & .859 & .671 \\
\hline & ES2 & 1.082 & .071 & 15.159 & $* * *$ & .840 & .706 & & \\
\hline & ES3 & 1.057 & .072 & 14.668 & $* * *$ & .791 & .626 & & \\
\hline \multirow[t]{3}{*}{ EL } & EL1 & 1.000 & & & & .762 & .581 & .848 & .651 \\
\hline & EL2 & 1.157 & .084 & 13.844 & $* * *$ & .895 & .801 & & \\
\hline & EL3 & 1.001 & .075 & 13.312 & $* * *$ & .756 & .572 & & \\
\hline
\end{tabular}

Note: $\mathrm{FL}=$ Factor Loading; $\mathrm{IR}=$ Item Reliability; $\mathrm{CR}=$ Composite Reliability; $\mathrm{CV}=$ Convergent Validity

In Table 1, it is easy to figure out the standardized loading estimates (factor loadings) of all items are significant ( $\mathrm{p}<.001)$ and surpass the benchmark point .6 (Hair, 2010). Meanwhile, all the SMC values were above the cutoff point (.5); all the values of composite reliability for 6 latent variables were between .848 and .914 , much higher than the threshold value (ideally 0.7 or more) (Fornell \& Larcker, 1981); the average of variance extracted (AVE) for all the dimensions were ranging from .651 to .779 exceeding the reasonable thresholds 0.5 (Hair et al., 2014); in terms of discriminant validity, most of the square root of AVEs were more elevated than either of the correlation between any two constructs or any other construct (Table 2), except the square root of AVE for EL. But it was just slightly lower than ES, so it was still considered in the acceptable range.

Table 2

The Result of Convergent Validity \& Discriminant Validity

\begin{tabular}{|c|c|c|c|c|c|c|c|}
\hline & AVE & EV & EL & ES & SV & PDV & FV \\
\hline $\mathbf{E V}$ & .711 & .843 & & & & & \\
\hline EL & .651 & .126 & .807 & & & & \\
\hline ES & .671 & .130 & .842 & .819 & & & \\
\hline SV & .779 & .065 & .713 & .796 & .883 & & \\
\hline PDV & .666 & .131 & .618 & .702 & .502 & .816 & \\
\hline FV & .683 & .055 & .616 & .730 & .460 & .469 & .826 \\
\hline
\end{tabular}

Diagonal elements (bold) $=$ square root of AVE 
To sum up, all the indices represents a high standard of validity and reliability, which lays a good foundation for further SEM analysis.

\subsection{The Structural Model Analysis}

The goodness fit indices of this research are all within the acceptable range. GFI (.939), AGFI (.917), TLI (.983), and CFI (.986), were more significant than the .9 benchmark value, while REMSEA (.035), and SRMR (.033) lowered than the cutoff point (.08). As for chi-square value and the probability value, due to a huge sample size ( $\mathrm{n}>=200$ ), sig probability could not be taken into account (Hair, 2013) so it conducted the ratio of chi-square to degrees of freedom $(\mathrm{x} 2 / \mathrm{d} . \mathrm{f}$. $=1.393)$, which fell within the suggested value of 3 or below. According to the result, it can conclude that the overall model has been by the data and can be analyzed further.

Table 4

Structural Regression Weight $(\mathrm{n}=327)$

\begin{tabular}{|c|c|c|c|c|c|c|}
\hline & Vari & & $\mathbf{P}$ & SE & Result & SMC \\
\hline \multirow{4}{*}{ ES } & $\leftarrow$ & FV & $* * *$ & .346 & $\mathrm{H}_{1 \mathrm{a}}$ Supported & \multirow[t]{4}{*}{.858} \\
\hline & $\leftarrow$ & PDV & $* * *$ & .276 & $\mathrm{H}_{1 \mathrm{~b}}$ Supported & \\
\hline & $\leftarrow$ & EV & .243 & .028 & $\mathrm{H}_{1 \mathrm{c}}$ Rejected & \\
\hline & $\leftarrow$ & SV & $* * *$ & .376 & $\mathrm{H}_{1 \mathrm{~d}}$ Supported & \\
\hline \multirow{5}{*}{ EL } & $\leftarrow$ & ES & $* * *$ & .856 & $\mathrm{H}_{2}$ Supported & \multirow[t]{5}{*}{0.717} \\
\hline & $\leftarrow$ & FV & .556 & .048 & $\mathrm{H}_{3 \mathrm{a}}$ Rejected & \\
\hline & $\leftarrow$ & PDV & .314 & .075 & $\mathrm{H}_{3 \mathrm{~b}}$ Rejected & \\
\hline & $\leftarrow$ & EV & .625 & .018 & $\mathrm{H}_{3 \mathrm{c}}$ Rejected & \\
\hline & $\leftarrow$ & SV & .151 & .117 & $\mathrm{H}_{3 \mathrm{~d}}$ Rejected & \\
\hline
\end{tabular}

Research results revealed that: the path coefficients from FV, PDV, and SV to ES were $.369, .283, .049$ respectively which significantly supported the hypotheses, while only the parameter estimate (.045) for the relationship between EV and ES was insignificant; on the other hand, only ES had significant association with EL (.856) and all the dimensions of the perceived value did not have substantial direct impact on EL. Additionally, SMC is used to measure the explained variance of latent variables relative to their total variance. Following the suggestion of Chin (1998) and Ringle (2004), the value of approximately .760 was considered substantial, and values around .333 were moderate. In this case, notably, $85.8 \%$ of the variance in ES and $71.7 \%$ of the variation in EL surpassed and closed to the substantial level respectively, implying they were powerfully explained by its antecedents and demonstrated the strong direct effect among them. To be concluded, relying on empirical study, it confirms the $\mathrm{H}_{1 \mathrm{a}}, \mathrm{H}_{1 \mathrm{~b}}, \mathrm{H}_{1 \mathrm{~d}}$, and $\mathrm{H}_{2}$ and proves there are significant associations between those variables.

\subsection{Mediation Analysis}

The results of this research also present that influences of Perceived Value (FV, PDV, EV, and SV) on EL distributed through ES (mediator) are statistically significant (Table 5). Based on Baron and Kenny's (1986) causal steps approach, the intervening variable effect (ES) existed between PV and EL. However, Baron and Kenny's causal steps approach is among the lowest in power (Fritz and MacKinnon, 2007). Hence the Sobel test (Sobel, 1986) is employed as a supplement to Baron and Kenny's approach to overcoming this weakness (Hayes, 2009). But Sobel test assumes sampling data spread in the normal distribution. Indeed, it is possible to get a normally distributed sampling in the empirical study (Bollen \& Stine, 1990; Alkhawaldeh et al., 2020). Of the alternatives, bootstrap is deemed the optimal approach (Mackinnon et al., 2002), which employs computerintensive resampling to make inferences rather than making assumptions about the population (Hayes, 2009). Therefore, bootstrap (5000 samples with 95\% confidence interval) was adopted in this research to test the intervening effect of consumer satisfaction.

Table 5

The analysis result of direct, indirect, and total effects of the hypothesized model

\begin{tabular}{|c|c|c|c|c|c|c|c|}
\hline & \multirow{3}{*}{ Point Est } & & & \multicolumn{4}{|c|}{ Bootstrapping } \\
\hline & & \multicolumn{2}{|c|}{ Production of Coefficients } & \multicolumn{2}{|c|}{$\begin{array}{c}\text { Bias-corrected } \\
95 \% \mathrm{CI}\end{array}$} & \multicolumn{2}{|c|}{$\begin{array}{c}\text { Percentile } \\
95 \% \text { CI }\end{array}$} \\
\hline & & SE & $\mathrm{Z}$ & Lower & Upper & Lower & Upper \\
\hline FVtoEStoEL (IE) & .226 & .132 & 1.712 & .078 & .451 & .090 & .468 \\
\hline FVtoEL (DE) & .048 & .143 & .336 & -.199 & .233 & -.205 & .230 \\
\hline TotalFV & .273 & .086 & 3.174 & .101 & .439 & .113 & .451 \\
\hline PDV toEStoEL(IE) & .180 & .091 & 1.978 & .064 & .392 & .063 & .389 \\
\hline PVtoEL (DE) & .075 & .109 & .688 & -.155 & .249 & -.160 & .248 \\
\hline TotalPV & .256 & .079 & 3.241 & .093 & .402 & .100 & .406 \\
\hline EVtoEStoEL(IE) & .021 & .031 & .677 & -.016 & .092 & -.020 & .082 \\
\hline EVtoEL (DE) & .018 & .044 & .409 & -.059 & .104 & -.065 & .098 \\
\hline TotalEV & .039 & .039 & 1.000 & -.029 & .123 & -.034 & .116 \\
\hline SVtoEStoEL(IE) & .245 & .124 & 1.976 & .091 & .438 & .105 & .467 \\
\hline SVtoEL (DE) & .117 & .134 & .873 & -.104 & .311 & -.126 & .296 \\
\hline TotalSV & .362 & .056 & 6.464 & .253 & .469 & .259 & .476 \\
\hline
\end{tabular}

Note Standard estimating of 5000 bootstrap sample; IE=Indirect Effect; DE=Direct Effect. 
As shown in Table 5, both bias-corrected 95\% confidence interval (CI) and percentile 95\% CI relating those FV, PV, and SV indirect influence did not include zero, which indicated the intervening effects of ES are significantly different from zero; so did the total effects; while, both bias-corrected $95 \%$ CI and percentile $95 \%$ CI regarding with all the direct effects of FV, PDV, and SV included zero that emphasized there were no direct effect between them and EL. Therefore, E-satisfaction fully intervened in the relation between FV, PDV, SV, and EL. On the other hand, there is an insignificance mediation effect of ES on the relationship between EV and EL since its bias-corrected $95 \%$ confidence interval (CI) and percentile $95 \% \mathrm{CI}$ all contain zero.

\section{Conclusion and discussion}

According to the results, it is found that perceived functional value, procedural value, and social value except for emotional value significantly and positively impact on e-loyalty through e-satisfaction in the context of Sino-Thai Cross-border E-commerce. Although all of those are significant antecedents of e-satisfaction and e-loyalty, in empirical test, apparently social value has a stronger association concerning e-loyalty compared with functional value and procedural value, the following is functional value and the least is procedural value. Hence, this phenomenon presents that those 3 factors control and impact eloyalty in varying levels in Sino-Thai Cross-border E-commerce indirectly based on e-satisfaction. Besides, the findings stress that the full mediating effect of e-satisfaction within the Sino-Thai Cross Border E-commerce domain on the relationship leading to customer loyalty to firms as well. Without e-satisfaction, e-loyalty is not able to be established or enhanced by controlling perceived functional value, procedural value, and social value. Based on the analysis of the result, this research contributes to the theory by providing a specific industry Sino-Thai Cross-border E-commerce and by testing the new conceptual model. Moreover, this research examines the effect of perceived functional value, procedural value, emotional value, and social value towards e-loyalty through e-satisfaction, which all together have never been tested in the context of SinoThai Cross-border E-commerce before. By doing so, it can be addressed close the literature gap and contributed with more knowledge to industry and subject.

\section{Limitation and recommendations}

There are several limitations of this research that should be considered when it would extend to interpret or manifest in other industries in the future. Firstly, it is restricted to the context of Sino-Thai Cross-border E-commerce, and any generalization or extension to other industries shall be required to re-examine to make sure the accuracy and reliability of this conceptual model. Secondly, the research is based on typical China's customers in Sino-Thai Cross-border E-commerce and is not focused on those from the specific platforms or website. Although the general principles followed are sound, within the broad products or services in Sino-Thai Cross-border E-commerce, the e-loyalty model may not applicable to all types of products or services industry. This limitation of the study also recommended that any potential future researches are allowed to narrow down to any specific products or industry to verify the applicability of this conceptual model. Thirdly, the measures or scales in the study are adapted from prior studies, not specifically designed for the context of Sino-Thai Cross-border E-commerce. Hence, it encourages scholars and researchers to employ qualitative analysis to design and create new measurement scales to evaluate e-loyalty under Sino-Thai Cross-border E-commerce more accurately.

\section{Acknowledgement}

The authors would like to thank the anonymous referees for constructive comments on earlier version of this paper.

\section{References}

Alkhawaldeh, A., Alsaad, A., Taamneh, A., \& Alhawamdeh, H. (2020). Examining antecedents and consequences of university brand image. Management Science Letters, 10(5), 953-960.

Baron, R. M., \& Kenny, D. A. (1986). The moderator-mediator variable distinction in social psychological research: Conceptual, strategic, and statistical considerations. Journal of Personality and Social Psychology, 51(6), 1173-1182.

Bollen, K. A., \& Stine, R. (1990). Direct and indirect effects: Classical and bootstrap estimates of variability. Sociological Methodology, 20, 115-140.

Brady, M.K., \& Robertson, C.J. (1999). An Exploratory Study of Service Value in the USA and Ecuador. International Journal of Industry Management, 10(5), 469-86.

Brown, J. D. (2011). Likert items and scales of measurement? SHIKEN: JALT Testing \& Evaluation SIG Newsletter, 15(1) 10-14.

Carlson, J., O'Cass, A., \& Ahrholdt, D. (2015). Assessing customers' perceived value of the online channel of multichannel retailers: A two country examination. Journal of Retailing and Consumer Services 27 (2015), 90-102.

Chin, W.W. (1998). The Partial Least Squares Approach for Structural Equation Modeling. Modern Methods for Business Research, 295-336.

Chinese Demand for Thai Durian Skyrockets. (2018, May 29). Thephuketnew. Retrived March 1, 2019, from https://www.thephuketnews.com/chinese-demand-for-thai-durian-skyrockets-67278.php. 
Cross-border E-commerce in China: A New Opportunity. (2019, Jan 27). Marketingtochina. Retrived March 1, 2019, from https://www.marketingtochina.com/cross-border-china.

Fornell, C., \& Larcker, D. F. (1981). Evaluating structural equation models with unobservable variables and measurement error. Journal of Marketing Research, 18(1), 39-50.

Fritz, M. S., \& MacKinnon, D. P. (2007). Required sample size to detect the mediated effect. Psychological Science, 18, 233239.

Goutam, D., \& Gopalakrishna, B. (2018). Customer loyalty development in online shopping: An integration of e-service quality model and commitment-trust theory. Management Science Letters, 8(11), 1149-1158.

Hair, J.F., Black, W.C., Babin, B.J. and Anderson, R.E. (2010) Multivariate Data Analysis. 7th Edition, Pearson, New York.

Hair, J. F., Hult, G. T. M., Ringle, C. M., \& Sarstedt, M. (2014). A Primer on Partial Least Squares Structural Equation Modeling (PLS-SEM). Thousand Oaks: Sage.

Hair, J. F., Ringle, C.M., \& Sarstedt, M.(2013). Partial least squares structural equation modeling: Rigorous applications, better results and higher acceptance. Long Range Planning 46(1-2):1-12.

Hansen, P., \& Jonsson, S. (2014). Another Colonialism: Africa in the History of European Integration. Journal of Historical Sociology, 27(3), 442-461.

Hayes, A. F. (2009). Beyond Baron and Kenny: Statistical mediation analysis in the new millennium. Communication Monographs, 76(4), 408-420.

Is Chinese durian love a fad or forever. (2018, May 30). Bangkokpost. Retrived April 2, 2019, from https://www.bangkokpost.com/thailand/special-reports/1475525/is-chinese-durian-love-a-fad-or-forever.

Jayakodi, D.H., Samarasinghe, D., \& Kuruppu, G. (2016). The Effect of Customer Perceived value on Customer Satisfaction \& Loyalty: A Case of Sri Lankan Pay-TV Industry. In Researchgate.

Jarvis, L.P., \& E.J. Mayo. (1986). Winning the Market-Share Game. Cornell Hotel Restaurant Administration Quarterly, 27(3 0), 72-79, November 1986.

Kassim, N., \& Abdullah, N. (2008). Customer Loyalty in e-Commerce Settings: An Empirical Study. Electronic Markets,18, 275-290.

Kotler, P., \& Singh, R. (1981). Marketing Warfare. Journal of Business Strategy, 1, 30.

Kungumapriya, A., \& Malarmathi, K. (2018). The impact of service quality, perceived value, customer satisfaction in calculative commitment and customer loyalty chain in Indian mobile telephone sector. Journal of Business and Management, 20(5), $72-82$.

Liu, L., \& Zhang, N. (2016) Research on the relationship between customer perceived value, satisfaction and Loyalty- Empricial Analysis based on the Electronic Commerce Market. Journal of Information Resources Management, 3, 50-57.

MacKinnon, D. P., Lockwood, C. M., Hoffman, J. M., West, S. G., \& Sheets, V. (2002). A comparison of methods to test mediation and other intervening variable effects. Psychological Methods, 7, 83-104.

Nilson, T.H. (1992), Value-addedMarketing, McGraw-Hill, London.

Ngo, T., Tran, T., Tran, M., Nguyen, Q., \& Hoang, V. (2019). A study on relationship between cultural industry and economic growth in Vietnam. Management Science Letters, 9(6), 787-794.

Nguyen, T., Tran, N., Doan, X., \& Nguyen, H. (2020). The impact of knowledge sharing on innovative work behavior of Vietnam telecommunications enterprises employees. Management Science Letters, 10(1), 53-62.

Quan, N., Chi, N., Nhung, D., Ngan, N., \& Phong, L. (2020). The influence of website brand equity, e-brand experience on e-loyalty: The mediating role of e-satisfaction. Management Science Letters, 10(1), 63-76.

Reichheld, B. Y. F. E., and Detrick, C. (2003). Want to Know How to Keep Expenses Low? Think loyalty. American Banker,168(181),6.

Rolph, E. A., \& Srini, S. S. (2003). E-Satisfaction and E-Loyalty: A Contingency Framework. Psychology \& Marketing, 20(2), 123-138 (February 2003).

Ringle, W. M. (2004). On the Political Organization of Chicken Itza. Ancient Mesoamerica, 15, 176-218.

Sharp, B., \& A. Sharp. (1997). Loyalty Programs and Their Impact on Repeat-Purchase Loyalty Patterns. International Journal of Research in Marketing 14(5), 473-486.

Sheth, J., Newman, B., \& Gross, B. (1991). Why We Buy What We Buy: A Theory of Consumption Values. Journal of Business Research, 22, 159-170.

Sobel, M. E. (1986). Some new results on indirect effects and their standard errors in covariance structure models. In N. Tuma (Ed.), Sociological Methodology (pp. 159-186). Washington, DC: American Sociological Association.

Sweeney, J., \& Soutar, G. (2001). Consumer Perceived Value: The Development of a Multiple Item Scale. Journal of Retailing, 77, 203-220.

The Science of Customer Satisfaction. (n.d.). In ACIS. Retrieved April 2, 2019, from https://www.theacsi.org/about-acsi/thescience-of-customer-satisfaction.

Unique Benchmarking Capability. (n.d.). In ACIS. Retrieved April 2, 2019, from https://www.theacsi.org/about-acsi/uniquecustomer-satisfaction-benchmarking-capability. 
(C) 2020 by the authors; licensee Growing Science, Canada. This is an open access article distributed under the terms and conditions of the Creative Commons Attribution (CC-BY) license (http://creativecommons.org/licenses/by/4.0/). 